\title{
UJI DAYA HAMBAT PERASAN BAWANG PUTIH (Allium sativum L) TERHADAP PERTUMBUHAN Aspergillus niger
}

\author{
Hafifah $^{1)}$, Tuty Widyanti' ${ }^{1)}$, Darmawaty Rauf ${ }^{1)}$, Mujahidah Basarang ${ }^{1)}$ \\ ${ }^{1)}$ Prodi DIII Teknologi Laboratorium Medis, Politeknik Kesehatan Muhammadiyah Makassar \\ Alamat Korespondensi: hafifa.lahiya@gmail.com
}

\begin{abstract}
Abstrak
Bawang putih (Allium sativum L) merupakan salah satu tanaman obat yang sering digunakan oleh masyarakat. Kandungan senyawa kimia yang dimiliki bawang putih berupa allicin, polifenol, ajoene, flavonoid, dan saponin yang berfungsi sebagai antimikroba dan antifungi. Salah satu jenis jamur yang bersifat patogen adalah Aspergillus niger. Jamur ini menyebabkan aspergillosis pada manusia yaitu penyakit saluran pernafasan, hati, ginjal, sistem saraf, otot, kulit, dan organ genital. Penelitian ini bertujuan untuk mengetahui kemampuan perasan bawang putih (Allium sativum L) dalam menghambat pertumbuhan Aspergillus niger dan untuk mengetahui konsentrasi perasan bawang putih (Allium sativum L) yang efektif dalam menghambat pertumbuhan Aspergillus niger. Penelitian ini dilakukan secara eksperimen laboratorium menggunakan metode difusi paper disc. Sampel penelitian ini adalah perasan bawang putih (Allium sativum L) yang dibuat dalam bentuk 4 konsentrasi yaitu 100\%, 80\%,60\% dan 40\%. Dari penelitian yang telah dilakukan hasil yang diperoleh untuk sampel perasan bawang putih dari masing-masing konsentrasi 100\%, 80\%, 60\%, dan 40\% didapatkan rata-rata hasil pengukuran diameter zona bening yaitu 43,5 mm, 36,1 mm, 35,3 mm, 28,3 mm. Berdasarkan dari hasil tersebut maka dapat disimpulkan bahwa perasan bawang putih dapat menghambat pertumbuhan Aspergillus niger.
\end{abstract}

Kata Kunci: Uji daya hambat, Perasan bawang putih (Allium sativum L), Aspergillus niger

\section{PENDAHULUAN}

Indonesia merupakan negara yang sangat kaya akan tanaman obat. Penggunaan tumbuh-tumbuhan sebagai pengobatan tradisional saat ini mulai meningkat peminatnya. Hal ini disebabkan karena dengan pengobatan tradisional lebih murah dan mengingat Indonesia memiliki potensi tumbuhan obat yang tinggi sehingga tidak sulit didapatkan. Salah satu tanaman obat yang sering digunakan masyarakat adalah bawang putih yang berkhasiat sebagai antimikroba, antifungi, antitrombotik, hipolipidemik, antiarthritis, hipoglikemik, dan juga memiliki antivitas sebagai antitumor (Hanum, 2011). Bawang putih memiliki kandungan senyawa kimia yaitu allicin, polifenol, ajoene, flavonoid, dan saponin (Sukma, 2016).

Senyawa allicin dan flavonoid bersifat merusak membran sel jamur sehingga terjadi permeabilitas sel yang mengakibatkan terhambatnya pertumbuhan sel atau matinya sel dan polifenol dapat mendanuturasi protein sel jamur (Pelczar dan Chan 1988).

Berdasarkan penelitian yang dilakukan oleh Rizqina Bintari, et al (2017) tentang uji aktivitas antifungi perasan bawang putih (Allium sativum L) terhadap Candida albiancas. Bahwa perasan bawang putih (Allium sativum L) dengan konsentrasi $25 \%, 50 \%$, dan $75 \%$ dapat menghambat pertumbuhan jamur Candida albiancas dengan besar diameter zona hambat rata-rata 1,61 mm, 13,57 mm, dan 3,16 mm.

Terdapat berbagai macam jamur yang bersifat patogen salah satunya adalah Aspergillus niger yang merupakan salah satu jenis spesies Aspergillus sp yang dapat menyebabkan aspergillosis pada manusia yaitu penyakit saluran pernafasan, hati, 
ginjal, sistem saraf, otot, kulit, dan organ genital (Ghautan et al. 2011).

Aspergillus sp adalah salah satu jamur yang dapat menghasilkan mikotoksin. Salah satunya adalah aflatoksin, yaitu jenis toksin yang bersifat karsiogenik dan hepatotoksik. Manusia dapat terpapar oleh aflatoksin dengan mengonsumsi secara terus menerus makanan yang terkontaminasi oleh toksin hasil dari pertumbuhan jamur Aspergillus sp (Nani, 2010).

Berdasarkan uraian di atas maka peneliti tertarik untuk melakukan penelitian ini untuk mengetahui uji daya hambat perasan bawang putih (Allium sativum L) terhadap pertumbuhan Aspergillus niger sehingga diharapkan bawang putih dapat menjadi obat herbal alami dalam pengobatan dan pencegahan berbagai penyakit akibat jamur Aspergillus niger.

\section{METODE PENELITIAN}

\section{Alat dan Bahan}

Alat yang digunakan pada penelitian ini adalah tabung reaksi, breaker glass, pisau, lumpang, alu, sendok tanduk, corong steril, hot plate, erlenmeyer, batang pengaduk, bunsen, timbangan analitik, labu ukur, autoklaf, inkubator, jangka sorong, labu ukur, lemari es, ose, rak tabung, pipet volume, pinset, kain kasa streil, kapas, dan oven.

Bahan yang digunakan pada penelitian ini adalah bawang putih (Allium sativum L), jamur Aspergillus niger, akuades, media Sabaround Dextrose Agar (SDA), paper disc, antibiotik chloromphenicol, kontrol positif ketoconazole dan aluminium foil.

\section{Prosedur Kerja}

Sterilisasi alat

Diterilisasikan alat dengan cara dicuci semua alat menggunakan sabun kemudian dibilas dengan air bersih setelah itu dibiarkan hinga mengering kemudian sterilkan dalam oven pada suhu $121^{\circ} \mathrm{C}$ selama 12 menit.

\section{Persiapan sampel}

Bawang putih dipisahkan dari kulitnya terlebih dahulu, kemudian ditimbang sebanyak 250 gr menggunakan timbangan analitik. Sampel bawang putih dicuci menggunakan akuades, kemudian ditumbuk bawang putih hingga halus menggunakan lumpang dan alu. Setelah itu dilakukan pemerasan dengan kain kasa steril dan dimasukkan ke dalam erlenmeyer. Pembuatan medium Sabaround Dextrose $\operatorname{Agar}(S D A)$

Media SDA ditimbang sebanyak 9,75 gram kemudian ditambahkan akuades sebanyak $150 \mathrm{ml}$ selanjutnya dimasukkan ke dalam Erlenmeyer kemudian di homogenkan menggunakan batang pengaduk dan bantuan pemanasan. Proses pemanasan menggunakan hot plate tidak boleh sampai mendidih untuk menghindari terbentuknya Kristal pada dinding Erlenmeyer. Media kemudian ditutup dengan aluminium foil setelah itu disterilisasikan dengan autoklaf salama 15 menit pada suhu $121^{\circ} \mathrm{C}$. Selanjutnya ditambahkan larutan antibiotik chloramphenicol sebanyak 1,5 ml. kemudian dituang kedalam cawan petri steril dengan cara aseptic hingga membeku pada suhu kamar dengan posisi cawan petri dibalik.

Pembuatan larutan kontrol (+) dan kontrol $(-)$

Kontrol positif menggunakan obat ketoconazole dengan pembuatan konsentrasi $2 \%$ dibuat dengan cara ditimbang $0,3 \mathrm{~g}$ ketoconazole kemudian dilarutkan dengan akuades steril sebanyak $1 \mathrm{ml}$ dan kontrol negatif menggunakan akuades steril sebanyak $1 \mathrm{ml}$. Setelah pembuatan larutan kontrol positif dan kontrol negatif paper disc di rendam selama 15 menit.

\section{Pembuatan perasan bawang putih}

Perasan bawang putih (Allium sativum L) dipipet sebanyak $10 \mathrm{ml}$ dimasukkan ke dalam cawan petri yang telah diberi label konsentrasi $100 \%$ berisi paper 
disc steril. Paper disc direndam selama 15 menit.

Sampel perasan bawang putih (Allium sativum $L$ ) dipipet sebanyak $8 \mathrm{ml}$ setelah itu dimasukkan kedalam labu ukur $(10 \mathrm{~mL})$ kemudian tambahkan aquades sampai tanda batas. Perasan bawang putih konsentrasi $80 \%$ yang telah dihomogenkan dituang ke dalam cawan petri yang berisi paper disc steril. Paper disc direndam selama 15 menit.

Sampel perasan bawang putih (Allium sativum $L$ ) dipipet sebanyak $6 \mathrm{ml}$ setelah itu dimasukkan kedalam labu ukur $(10 \mathrm{~mL})$ kemudian tambahkan aquades sampai tanda batas. Perasan bawang putih konsentrasi $60 \%$ yang telah dihomogenkan dituang ke dalam cawan petri yang berisi paper disc steril. Paper disc direndam selama 15 menit.

Sampel perasan bawang putih (Allium sativum $L$ ) dipipet sebanyak $4 \mathrm{ml}$ setelah itu dimasukkan kedalam labu ukur (10 mL) kemudian tambahkan aquades sampai tanda batas. Perasan bawang putih konsentrasi $40 \%$ yang telah dihomogenkan dituang ke dalam cawan petri yang berisi paper disc steril. Paper disc direndam selama 15 menit.

Pengujian daya hambat menggunakan metode difusi

Biakan jamur Aspergillus niger diambil satu ujung ose steril kemudian diikunolasikan atau digoreskan pada medium SDA kemudian diletakkan Paper disk yang telah direndam pada setiap konsentrasi $(100 \%, 80 \%, 60 \%$, dan 40\%). Dan juga kontrol positif dan kontrol negatif di atas permukaan media selanjutnya diinkubasi selama $1 \times 24$ jam pada suhu $30^{\circ} \mathrm{C}$ kemudian dilakukan pengamatan dengan ada atau tidak zona hambat (wilayah jernih) yang terbentuk disekitar kertas cakram paper disk (kuswiyanto, 2015).

Pengukuran zona hambat

Pengukuran zona hambat ini dilakukan dengan cara mengambil garis horizontal pada zona bening disekitar disk menggunakan jangka sorong.

\section{Interpretasi hasil}

Nilai diameter zona hambatan dianalisa secara deskriptif berdasarkan kategori respon hambat. Zona hambat perasan bawang putih dibandingkan dengan zona hambat kontrol positif (Ketoconazole) dengan nilai sebagai berikut:

Resisten $\quad: \leq 20 \mathrm{~mm}$

Intermediet $: 21-27 \mathrm{~mm}$

Sensitif $: \geq 28 \mathrm{~mm}$ (CLSI, 2014).

\section{HASIL DAN PEMBAHASAN}

Berdasarkan penelitian tentang uji daya hambat perasan bawang putih (Allium sativum L) terhadap pertumbuhan Aspergilllus niger pada penelitian ini menggunakan metode paper disk dengan kultur swab. Terdapat empat kelompok perlakuan dengan konsentrasi perasan bawang putih (Alium sativum L) yang berbeda yaitu: $100 \%, 80 \%, 60 \%, 40 \%$ serta dua kelompok kontrol yaitu kontrol posistif yang menggunakan ketonkonazole dan kontrol negatif menggunakan akuades steril. Hasil yang diperoleh dapat dilihat di tabel 1 .

Tabel 1. Zona Hambat Perasan Bawang Putih (Allium sativum L) terhadap Pertumbuhan Aspergillus niger

\begin{tabular}{lcl}
\hline Perlakuan & $\begin{array}{c}\text { Rata-rata } \\
\text { Diameter } \\
\text { Zona } \\
\text { Hambat } \\
\text { (mm) }\end{array}$ & $\begin{array}{c}\text { Interpretasi } \\
\text { Hasil }\end{array}$ \\
\hline $\begin{array}{l}\text { Konsentrasi } \\
100 \%\end{array}$ & 43,5 & Menghambat \\
$\begin{array}{l}\text { Konsentrasi } \\
80 \%\end{array}$ & 36,1 & Menghambat \\
$\begin{array}{l}\text { Konsentrasi } \\
60 \%\end{array}$ & 35,3 & Menghambat \\
$\begin{array}{l}\text { Konsentrasi } \\
40 \%\end{array}$ & 28,3 & Menghambat \\
$\begin{array}{l}\text { Kontrol } \\
\text { positif } \\
\text { Kontrol } \\
\text { negatif }\end{array}$ & 26,8 & Menghambat \\
\hline
\end{tabular}


Dari penelitian yang telah dilakukan, didapatkan hasil bahwa dari tiga kali pengulangan didpatkan pada masing-masing konsentrasi rata-rata hasil pengukuran diameter zona hambat untuk konsentrasi $100 \%$ sebesar $43,5 \mathrm{~mm}$, konsentrasi $80 \%$ sebesar 36,1 mm, konsentrasi $60 \%$ sebesar $35,3 \mathrm{~mm}$, dan pada konsentrasi $40 \%$ sebesar $28,3 \mathrm{~mm}$.

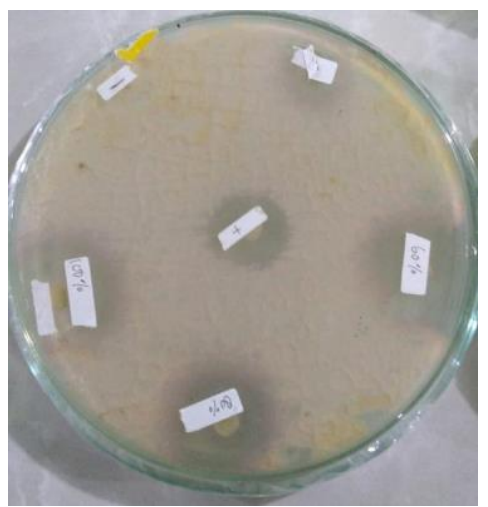

Gambar 1. Zona Hambat

Berdasarkan dari interpretasi hasil menurut CLSI, 2014 tersebut maka dapat disimpulkan bahwa hasil $>18 \mathrm{~mm}$ artinya semuanya bersifat sensitif terhadap pertumbuhan Aspergillus niger. Diameter zona hambatan dianalisis secara deskriptif berdasarkan kategori respon hambat yaitu Resisten $<12 \mathrm{~mm}$, Intermediet, 13-17 mm, dan sensitif $>18 \mathrm{~mm}$.

Hasil yang diperoleh ini sesuai dengan penelitian yang dilakukan oleh Rizqina Bintari, et., al. (2017) tentang uji aktivitas antifungi perasan bawang putih (Allium sativum L) terhadap Candida albiancas. Bahwa perasan bawang putih (Allium sativum L) dengan konsentrasi $25 \%, 50 \%$, dan $75 \%$ dapat menghambat pertumbuhan jamur Candida albiancas dengan besar diameter zona hambat rata-rata $1,61 \mathrm{~mm}$, $13,57 \mathrm{~mm}$, dan $3,16 \mathrm{~mm}$.

Adanya zona bening yang terbentuk pada skitar paper disc yang menunjukan bahwa perasan bawang putih (Allium sativum $\mathrm{L}$ ) dapat menghambat pertumbuhan Aspergillus niger itu dapat dipengaruhi oleh beberapa faktor antara lain volume konsentrasi perasan yang tepat, waktu perendaman paper disk yang tepat. Selain itu adanya kemampuan perasan bawang putih (Allium sativum L) dalam menghambat pertumbuhan Aspergillus niger disebabkan oleh adanya kandungan senyawa kimia yaitu senyawa allicin dan flavonoid bersifat merusak membran sel jamur sehingga terjadi permeabilitas sel yang mengakibatkan terhambatnya pertumbuhan sel atau matinya sel dan polifenol dapat mendanuturasi protein sel jamur (Pelczar dan Chan 1988). Kerusakan sel jamur ini yang kemudian akan menghambat pertumbuhan Aspergillus niger.

Pada penelitian ini menggunakan kontrol positif berupa ketonkonazole dan kontrol negatif berupa aquades. Kedua kontrol ini digunakan sebagai indikator bahwa penelitian yang telah dilakukan sudah menggunakan prosedur sesuai standar yang telah ditentukan, untuk kontrol positif menunjukkan hasil pada bagian sekitar disk akan terbentuk zona bening yang mengindikasikan berfungsi antibiotik sebagai menghambat pertumbuhan jamur dan kontrol negatif menunjukan hasil pada bagian sekitar disk tidak terbentuk zona bening karena aquades tidak memiliki faktor penghambat jamur. Hal ini sudah sesuai dengan hasil pengukuran diameter zona bening pada kontrol negatif adalah $0 \mathrm{~mm}$ dan kontrol positif, rata-rata adalah $26,8 \mathrm{~mm}$.

Terbentuknya zona bening pada kontrol posistif karena antibiotik ketonkonazole ini memiliki mekanisme menghambat jamur dengan cara mengganggu sintesis ergestero yang merupakan komponen penting dari membran jamur. Selain penggunaan antibiotik Ketonkonazole di gunakan juga antibiotik Cholorompenicol antibiotik yang ditambahkan pada media SDA yang 
berfungsi untuk mencegah pertumbuhan bakteri (Rahmawati, et al 2019).

Dari kemampuan tersebut menunjukan bahwa bawang putih (Allium sativum L) dapat dijadikan sebagai pengobatan alternatif. Selain menghemat biaya pengobatan, bawang putih juga lebih aman dan tidak memiliki efek samping yang berbahaya sebagaimana antibiotik buatan.

\section{KESIMPULAN}

Sesuai dengan hasil penelitian yang telah dilakukan, maka dapat disimpulkan bahwa perasan bawang putih (Allium sativum $\mathrm{L}$ ) mampu mengambat pertumbuhan Aspergillus niger. Perasan bawang putih (Allium sativum L) pada konsentrasi 100\%, $80 \%, 60 \%, 40 \%$ efektif dalam menghambat pertumbuhan Aspergillus niger.

\section{SARAN}

Perlu dilakukan penelitian dengan menggunakan jamur yang berbeda, metode yang berbeda, dan jumlah sampel yang banyak.

\section{DAFTAR PUSTAKA}

Afzal, Savrat, et al. (2013). "Factors Behind Brand Switching In Cellular Networks", International Journal of Asian Social Science 3: (2)

Borlinghaus J., Frank A., Martin CHG, Ifeany DN Alan JS (2014). Allicin: Chemistry and Biological Properties Molicules 2014,19125912618

Clinical And Laboratory Standard Intuitute (CLSI), 2014. Performance Standards For Antimicrobial Suscepbtibility Testeing;Ggg Twenty-Fourt Informational Suplements: M100S24, Clinical And Laboratory Standards Intitute, Pennsylvania.

Gautam, A.K., R. Bhaduria. 2012. Characterizatian of Aspergillus species associated with commerciallynstoreed triphala powder. African journal Biotechnol 11 (104): 16814-16823.
Ghautam, A.K., Sharma S, Avasthi S, Bhaduria R, 2011. Deversity, Pathogenecity, and Toxikology of A.niger: an improtant spoilage fungi. Jiwaji university gwalior.

Hanum, M. (2011). Jamu Ala Kraton Sebagai Warisan Turun Teumurun Penerbit Andi: Yogyakarta

Hanani, S. 2013. Uji Efektivitas Larutan Bawang Putih Sebagai Insektisida Nabati Untuk Membunuh Larva Nyamuk Aedes Aegty. Skripsi,Gorontalo : universitas negri gorontalo.

Hakim, L. (2019). Buku pintar tumbuhan. PT. Elex Media. Jakarta.

Kuswiyanto. 2015. Buku Ajar Analis Kesehatan. Buku kedokteran EGC. Jakarta

Majewski, M. (2014). Allium sativum: facts and myths regarding human health. Roczniki Państwowego Zakładu Higieny, 65(1).

Nani, R. 2010. Bahan Ajar Mikrobiologi Pangan. Penerbit FTUN. Yogyakarta

Prapti, U. (2008). Buku Pintar Tanaman Obat. PT. Agromenia Pustaka. Jakarta.

Pelczar, M.J., Chan, E.C.S., 1998, Dasardasar Mikrobiologi. UI Press. Jakarta.

Rahmawati, R. 2012. Kemampuan Bawang Putih Tunggal (Bawang lanang). Yogyakarta: Pustaka Baru press.

Refai M, El-Yazid Ha, Hassan Atef 2014. Monograph On Aspergillus And Aspergillosis Ini Man, Animals, And Birds. AGuide Fpr Classification And Identification Of Aspergilli, Disease Caused By Them, Diagnosis And Treatement; 2014. 
Sukma, D. 2016. Sehat Tanpa Obat Bawang Merah dan Bawang Putih. Yogyakarta: Rapha Publishing Srikandi, F. 1992. Mikrobiologi Pangan I. Gramedia Pustaka Utama. Jakarta. Syaifurrisal, A., (2014. Pengaruh Penyimpanan Pakan Udang Komersial Dengan Penmabahan Volume Air Berbeda Pertumbuhan Jamur Dan Kandungan Protein Kasar, Skrip Fakultas Perikanan
Dan Kelauatan Universitas Air Langga Surabaya.

Siswandono dan soekardjo, B., 2000, Kimia Medinisial, Edisi 2, 228-232, 234, 239, Airlangga Univesity Press, Surabaya.

Wangge, E.S.A., D.N. Suprapta,G.N.A. Wirya.2012. Isolasi dan identifikasi jamur penghasil mitoksin pada biji kakao kering yang dihasilkan di flores. J.Agric. Sci. and Biotechnol 1910; 39 